\title{
REDISCOVERY OF IGLICA GRATULABUNDA (A. J. WAGNER, 1910) (CAENOGASTROPODA: TRUNCATELLOIDEA)
}

\author{
Hans D. Boeters ${ }^{1 *}$, AleXander ReischÜtZ², Peter ReischütZ², Michael UnRUH ${ }^{3}$
}

${ }^{1}$ Karneidstr. 8, D 81545 München, Germany (e-mail: boeters@t-online.de)

2Puechhaimgasse 52, A 3580 Horn, Austria (e-mail: alexander.reischuetz@gmx.at; peter.reischuetz@gmx.at)

${ }^{3}$ Schmale Str. 29, D 06712 Gutenborn, Germany (e-mail: michael.unruh@gmx.de)

*corresponding author

ABSTRACT: Iglica gratulabunda (A. J. Wagner, 1910) is redescribed based on conchological and anatomical characters; the interstitial of the river Mürz (Styria, Austria) is described as its habitat.

KEY WORDS: Truncatelloidea, Iglica gratulabunda, anatomy, Styria (Steiermark), Austria

\section{INTRODUCTION}

In 1910 ANTONI JÓZEF WAGNER described Vitrella gratulabunda from deposits of the river Mürz at Kapfenberg in Styria (Steiermark, Austria). The description was based on shell characters only. Three years later STURANY \& A. J. WAGNER (1914: 117) treated $V$. gratulabunda as a species of Paulia Bourguignat, 1882, i.e. Avenionia Nicolas, 1882. After the next 14 years A. J. WAGNeR (1928: 295) described the new genus Iglica and designated $V$. gratulabunda as its type species.

No live specimens of the species were found during more than a century (RADOMAN 1983: 110), possibly because of an inadequate understanding of the snail's habitat. Most malacologists seemed to have expected the species to inhabit karstic subterranean water courses, similarly to Bythiospeum. However, Kapfenberg on Mürz lies far downstream of the alpine calcareous zones.
Meanwhile many taxa were assigned to the genus, quite often doubtfully, for example by BOLE (1961: 59) and BOETERS (1971). On the other hand Iglica matjasici Bole, 1961 was included in Anagasta (RADOMAN 1973: 423), later corrected to Anagastina (RADOMAN 1978: 27). Based on anatomical and genetic investigations of Iglica cf. forumjuliana (Pollonera, 1887), Iglica cf. gracilis (Clessin, 1882), Iglica cf. hauffeni (Brusina, 1886) and Iglica hellenica Falniowski et Sarbu, 2015, allegedly belonging to Iglica, the genus was included in the Moitessieriidae (HOFMAN et al. 2018: 326, fig. 60, FALNIOWSKI et al. 2019: 66, fig. 12).

We made an attempt at solving the systematic position of Iglica. Our idea that Iglica gratulabunda might inhabit the interstitial of the river Mürz downstream of alpine calcareous zones led us finally to the discovery of live animals.

\section{METHODS}

Shells and animals, embedded in mud and gravel, were collected in a water level pipe by means of a dragnet (lumen diameter ca. $5 \mathrm{~cm}$ ), or a mechanical pump equipped with an un-perforated plastic tube (length $12 \mathrm{~m}$ ) fitted into the basal opening (diameter $3 \mathrm{~cm}$ ) of the pump.

Shells and animals were separated from the deposits by fractionating sieving through two sieves (mesh 
size 2.60 and $0.56 \mathrm{~mm}$ ). The animals were preserved in $75 \%$ ethanol for dissection and sequencing.

Whorls were counted according to GITTENBERGER et al. (1970). Dissection of soft parts followed BOETERS (1999). Drawings of shells, animals, their penis and renal oviduct were done with LEICA M80 Drawing Device. Length and diameter of shells were measured from the drawings $(60 \times$ magnification). Photographs of shells were taken with a Leica R8 digital system.

\section{SYSTEMATIC PART}

\section{Iglica gratulabunda (A. J. Wagner, 1910)}

Vitrella gratulabunda A. J. WAGNER (1910: 188, pl. 16, figs 21-22).

Type locality: “... im Geniste der Mürz bei Kapfenberg ...".

Paulia gratulabunda - STURANY \& A. J. WAGNER (1914: 117).

Iglica gratulabunda - A. J. WAGNER (1928: 295).

Iglica gratulabunda - BOETERS (1971: 173, figs 14a-b, syntype).

Material. Austria, Styria (Steiermark), Kapfenberg. (i) Deposits of river Mürz; Naturhistorisches Museum Wien (NMW)/Syntypes; (ii) vis-à-vis Mürzbogen (Fig. 1), water level pipe, $47^{\circ} 26^{\prime} 07.4^{\prime \prime} \mathrm{N}, 15^{\circ} 17^{\prime} 07.5^{\prime \prime} \mathrm{E}$; BOETERS, A. REISCHÜTZ, UNRUH leg. 25.06.2019; BOE 3507/animals and 3509/shells.

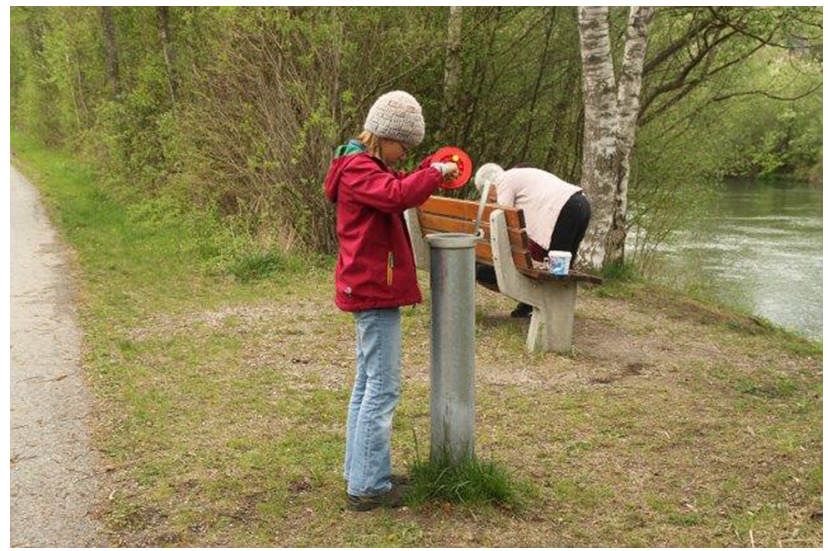

Fig. 1. Austria, Styria (Steiermark), Kapfenberg, water level pipe vis-à-vis Mürzbogen

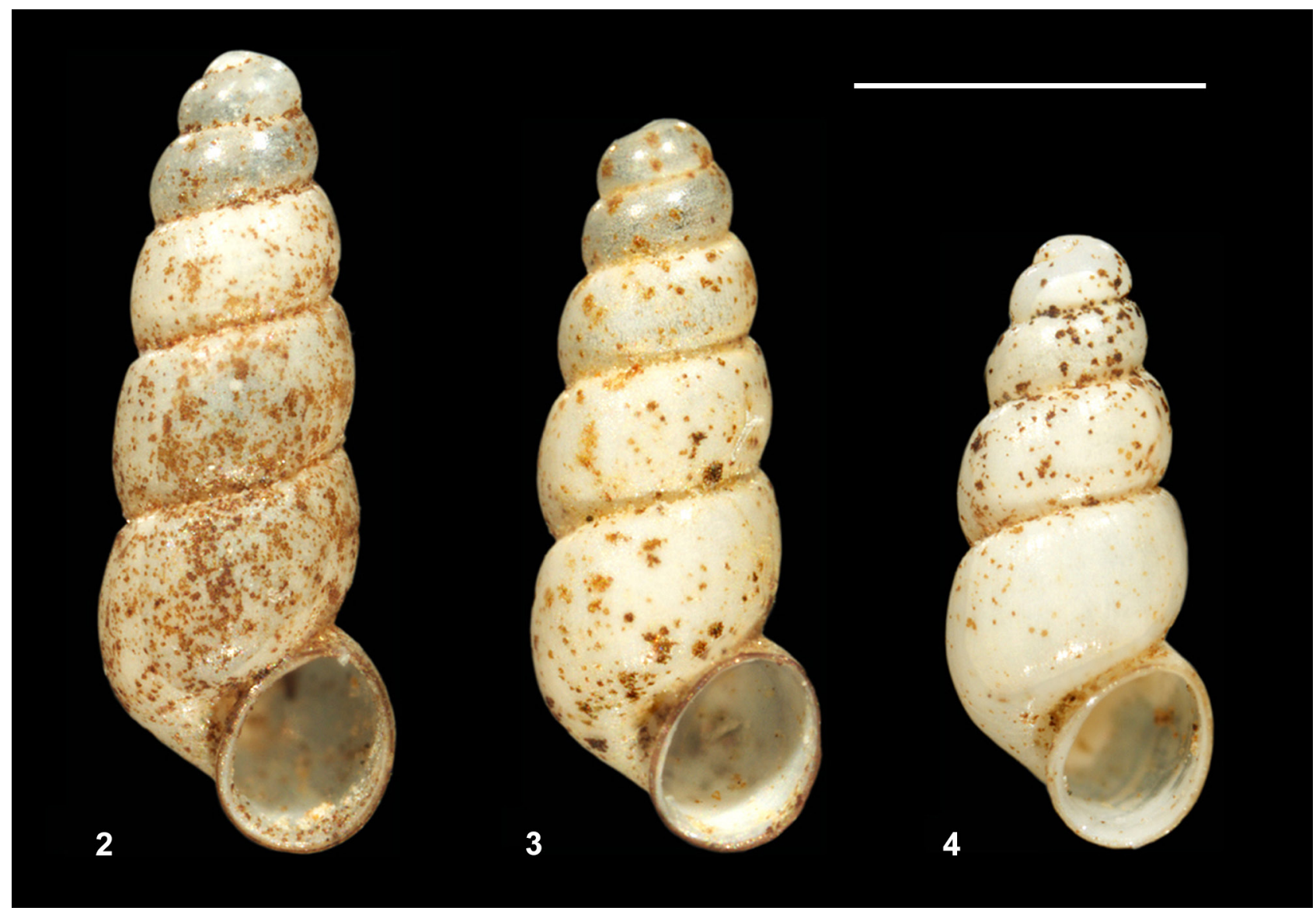

Figs 2-4. Iglica gratulabunda, Austria, Styria (Steiermark), Kapfenberg, Mürz, interstitial waters (BOE 3509). Photos: PETER GLÖER. Scale bar $1 \mathrm{~mm}$ 
Shell (Figs 2-4). 4.5-5.0 whorls $(\mathrm{N}=3)$. For measurements see Table 1. Operculum colourless.

Body. A line of black pigment spots runs down from the body whorl down to the stomach and covers or surrounds the style sac. Eye spots are missing. After

Table 1. Shell measurements [mm]

\begin{tabular}{ccc}
\hline Height & Diameter & Sex \\
\hline 1.73 & 0.73 & male \\
$?$ & 0.75 & male \\
1.88 & 0.80 & male \\
1.93 & 0.83 & male \\
1.92 & 0.83 & female \\
\hline
\end{tabular}

leaving the style sac, the intestine turns Z-like back to the stomach, then back towards the mantle cavity, and forms a second long Z-like loop in the roof of the cavity; in males this loop fills approximately the height of the body whorl, in females it flanks dorsally the stack of three glands, comprising the proximal albumen gland and the distal capsule gland. Ctenidium with seven lamellae (1 male).

Male (Figs 5-14). Penis in its resting state bent back below the second loop of the intestine; finger-like, without any outgrowth; vas deferens running centrally towards a minute papilla of the rounded apex of the penis.
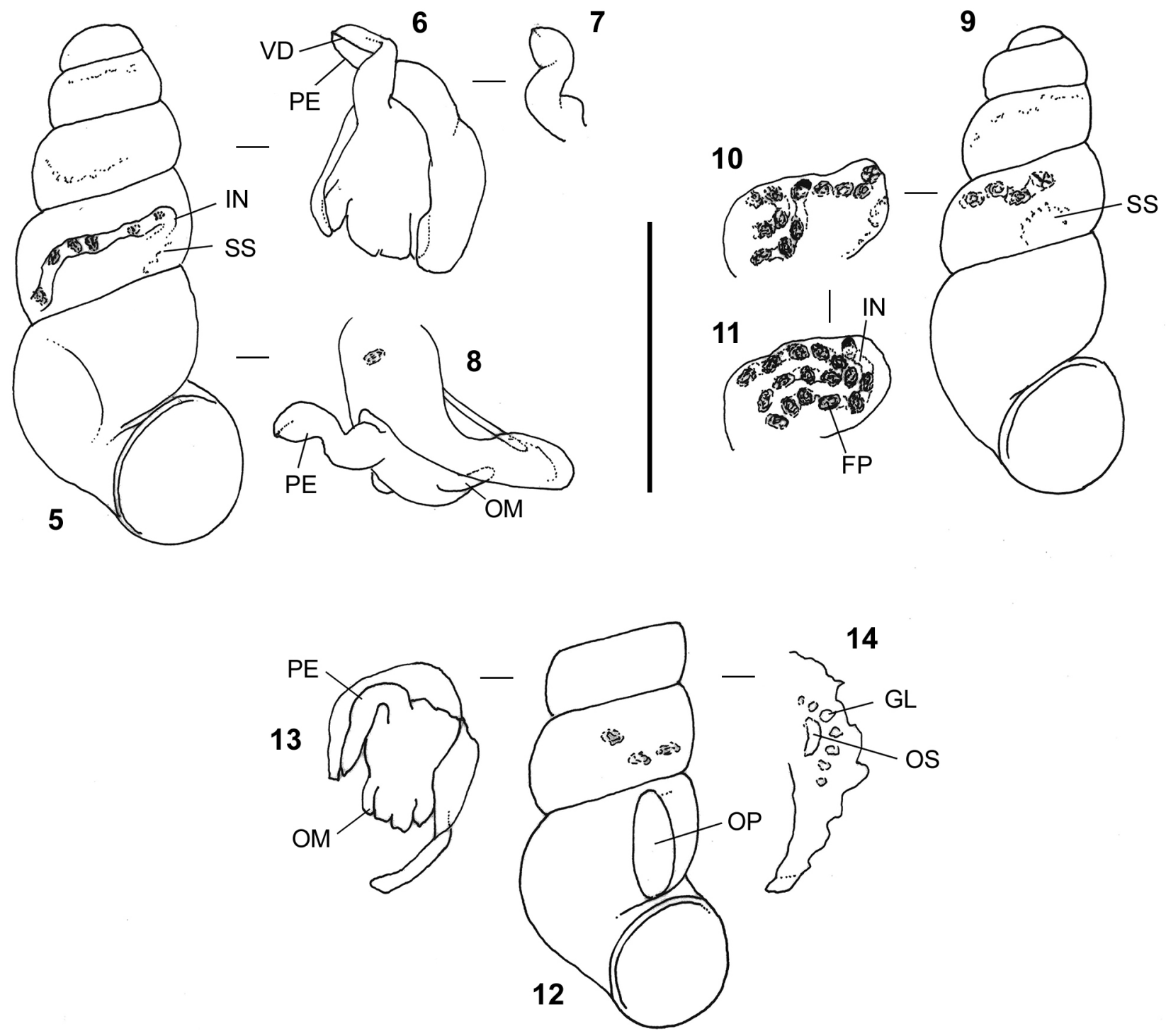

Figs 5-14. Males of Iglica gratulabunda, Austria, Styria (Steiermark), Kapfenberg, Mürz, interstitial waters (BOE 3507): 5-8 - 1st male (5 - animal, intestine seen through shell wall, 6 - head with penis exposed through slit in mantle, 7 penis, 8 - head-foot bulk with penis and operculum); 9-11-2nd male (9-animal, style sac and intestine seen through shell wall, 10-11 - body whorl with intestine seen through body wall); 12-14 - 3rd male (12 - fragmented animal with operculum in fragmented shell, 13 - head with penis exposed through slit in mantle, 14 - mantle fragment with ctenidium and osphradium). Abbreviations: FP - faecal pellet, GL - ctenidium lamella, IN - intestine, OM - ommatophore, OP - operculum, OS - osphradium, PE - penis, SS - style sac, VD - vas deferens. Scale bar $1 \mathrm{~mm}$ 


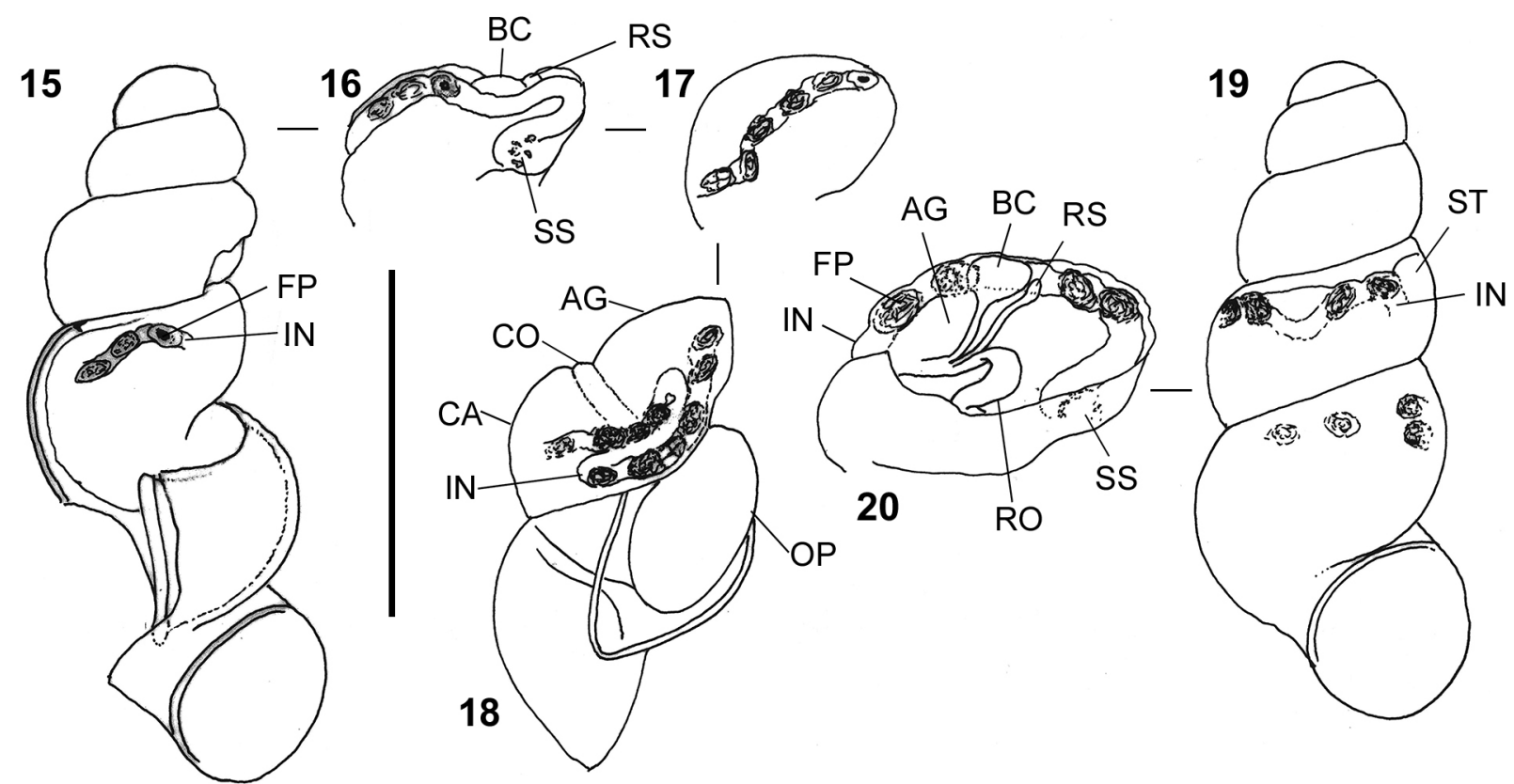

Figs 15-20. Females of Iglica gratulabunda, Austria, Styria (Steiermark), Kapfenberg, Mürz, interstitial waters (BOE 3507): 15-18 - 1st female (15 - animal with operculum in partially broken shell, 16-17 - body whorl with intestine seen through body whorl, 1st and 6th faecal pellet marked by cross and dot, respectively, 18 - body whorl with operculum and partially removed shell, loop of intestine seen through body wall); 19-20 - 2nd female (19 - animal seen through shell wall, 20 - body whorl with opened renal cavity, bursa and receptaculum in side view covered by intestine). Abbreviations: AG - albumen gland, BC - bursa copulatrix, CA - capsule gland, CO - covering gland, FP - faecal pellet, IN - intestine, OP - operculum, RO - renal oviduct, RS - receptaculum, SS - style sac, ST - stomach. Scale bar $1 \mathrm{~mm}$ for Figs 15-19 and 0.5 mm for Fig. 20

Female (Figs 15-20). Renal oviduct with a spherical bursa and a small receptaculum, leaning proximally on the bursa.

Habitat and distribution. Only known from Styria (Steiermark) in Austria, from interstitial waters of the

\section{DISCUSSION}

The anatomical characters correspond to those of Bythiospeum Bourguignat, 1882. However, Iglica differs in that the finger-like penis is not as slim as in Bythiospeum, that the ducts of the receptaculum and the bursa branch off the renal oviduct quite close to each other, and that the bursa is roundish sack-like and not cylindrical. A roundish sac-like bursa has already been shown by RADOMAN (1983: 11, fig. 57) for I. luxurians (Kuščer, 1932) and by HOFMAN et al. (2018: 323, fig. 5) for I. cf. forumjuliana (Pollonera, 1887). As regards Bythiospeum sp. from the interstitial of the river Neckar (type species Bythinella pellucida Wiedersheim, 1873 with the type locality "Neckarauswurf bei Cannstatt") reference is made to BOETERS (1984: 7 figs 3 ô and 5-6 우) and RICHLING river Mürz at Kapfenberg (sympatric with Bythinella sp.) and from deposits of a brook at Thal, W of Graz (REISCHÜTZ \& REISCHÜTZ 2009).

et al. (2017: 11, figs 6J 9 and 7D-E $\left.\partial^{\lambda}\right)$. The discrimination between Iglica and Bythiopeum should be supplemented by genetic analyses of the type species of Iglica.

\section{ACKNOWLEDGEMENTS}

We are very grateful to the employees of the Stadtwerke Kapfenberg, especially EWALD SCHREINER and ROBERT SCHMIEDER for their great support of our collecting efforts. We also thank HEIDE BOETERS (München) and HANNAH BOETERS (Truchtlaching) for supporting our sampling activities and PETER GLÖER (Hetlingen) for generously providing photographs. 


\section{REFERENCES}

BOETERS H. D. 1971. Iglica pezzolii n. sp. und ein neues Merkmal zur Unterscheidung zwischen Bythiospeum und Paladilhia (Prosobranchia, Hydrobiidae). Archiv für Molluskenkunde 101: 169-173.

BOETERS H. D. 1984. Zur Identität des Bythiospeum-Typus (Prosobranchia: Hydrobiidae). Heldia 1: 6-7.

BOETERS H. D. 1999. Präparation von Kleinprosobranchiern. Heldia 2 (Sonderheft 3): 9-15.

BOLE J. 1961. Nove Hidrobide (Gastropoda) iz podzemeljskih vod Zahodnega Balkana. Biološki Vestnik (Ljubljana) 9: 59-69.

FALNIOWSKI A., PREVORČNIK S., Delić T., Alther R. Altermatt F., Hofman S. 2019. Monophyly of the Moitessieriidae Bourguignat, 1863 (Caenogastropoda: Truncatelloidea). Folia Malacologica 27: 61-70. https:// doi.org/10.12657/folmal.027.005

GITTENBERGER E., BACKHUYS W., RIPKEN Th. E. J. 1970. De Landslakken van Nederland. Koninklijke Nederlandse Natuurhistorische Vereniging, Amsterdam.

HOFMAN S., RYSIEWSKA A., OSIKOWSKI A., GREGO J., SKET B., PREVORČNIK S., ZAGMAJSTER M., FALNIOWSKI A. 2018. Phylogenetic relationships of the Balkan Moitessieriidae (Caenogastropoda: Truncatelloidea). Zootaxa 4486: 311-339. https://doi.org/10.11646/zootaxa. 4486.3 .5

RADOMAN P. 1973. Anagasta un nouveau genre Prosobranchia et sa spéciation dans le bassin du lac Skadar. Zoologischer Anzeiger 190: 421-429.

RADOMAN P. 1978. Neue Vertreter der Gruppe Hydrobioidea von der Balkanhalbinsel. Archiv für Molluskenkunde 109: 27-44.

RADOMAN P. 1983. Hydrobioidea a superfamily of Prosobranchia (Gastropoda). I. Systematics. Serbian Academy of Sciences and Arts, Monographs 547, Department of Sciences 57: 1-256.

REISCHÜTZ A., REISCHÜTZ P. 2009. Mollusca (Weichtiere). In: RABITSCH W., ESSL F. (eds) Endemiten Kostbarkeiten in Österreichs Pflanzen- und Tierwelt. Naturwissenschaftlicher Verein für Kärnten \& Umweltbundesamt, Klagenfurt \& Wien, pp. 318-376.

RICHLING I., MALKOWSKY Y., KUHN J., NIEDERHÖFER H.-J., BOETERS H. D. 2017. A vanishing hotspot - the impact of molecular insights on the diversity of Central European Bythiospeum Bourguignat, 1881 (Mollusca: Gastropoda: Truncatelloidea). Organisms Diversity \& Evolution 17: 67-85. https://doi.org/10.1007/s13127016-0298-y

STURANY R., WAGNER A. J. 1914. Über schalentragende Landmollusken aus Albanien und Nachbargebieten. Denkschrift der kaiserlichen Akademie der Wissenschaften, mathematisch-naturwissenschaftliche Klasse 91: 19-138. https://doi.org/10.5962/bhl. title.10651

WAGNER A. J. 1910. Eine neue Vitrella aus dem Mürztale in Steiermark. Abhandlungen der senckenbergischen naturforschenden Gesellschaft 32: 188, pl. 16, figs 21-22.

WAGNER A. J. 1928. Studien zur Molluskenfauna der Balkanhalbinsel mit besonderer Berücksichtigung Bulgariens und Thraziens, nebst monographischer Bearbeitung einzelner Gruppen. Annales Zoologici Musei Polonici Historiae Naturalis [1927] 6: 263-399.

Received: August 21st, 2019

Revised: November 8th, 2019

Accepted: November 15th, 2019

Published on-line: November 28th, 2019 